\title{
Pengaruh Padat Tebar Terhadap Pertumbuhan Ikan Nila (Oreochromis niloticus) Dalam Sistem Akuaponik
}

\author{
Muh. Arzad', Ratna ${ }^{2}$, Ahmad Fahrizal ${ }^{3}$ \\ ${ }^{1}$ Mahasiswa di Universitas Muhammadiyah Sorong \\ ${ }^{2}$ Staf Pengajar di Universitas Muhammadiyah Sorong \\ Email : ratnathoriq@gmail.com \\ ${ }^{3}$ Staf Pengajar di Universitas Muhammadiyah Sorong \\ Email : a.fahriza.lab@gail.com
}

\begin{abstract}
Abstrak
Penelitian ini bertujuan sebagai berikut : 1) Untuk mengetahui cara budidaya ikan nila dengan sistem aquaponik. 2) Untuk mengetahui tingkat kepadatan yang terbaik dalam pertumbuhan ikan nila dalam sistem aquaponik. Metode pada penelitian ini menggunakan metode uji coba atau eksperimen dengan menggunakan model Rancangan Acak Lengkap (RAL). Penelitian ini terdiri dari 4 (empat) perlakuan dan 1 (satu) kontrol. Masing-masing perlakuan 3 kali ulangan. Padat tebar yang digunakan yaitu perlakuan I dengan padat tebar 20 ekor, perlakuan II 25 ekor, perlakuan III 30 ekor dan perlakuan IV dengan padat tebar 35 ekor. Tingkat kelangsungan hidup (SR) pada penelitian yaitu perlakuan I tingkat kelangsungan hidup (SR) $93.3 \%$, perlakuan II dengan tingkat kelangsungan hidup (SR) 92\%, perlakuan III tingkat kelangsungan hidup (SR) yaitu $94.4 \%$ dan perlakuan IV memiliki tingkat kelangsungan hidup (SR) yaitu $90.5 \%$. Kesimpulan dari penelitian menunjukkan bahwa teknik pendederan ikan nila pada sistem aquaponik pada umumnya sama dengan budidaya ikan biasa yang dilakukan dari, persiapan budidaya, pemeliharaan dan panen dan pasca panen. Tingkat kepadatan yang ideal adalah pada perlakuan ketiga dengan kepadatan 30 ekor dan tingkat kelangsungan hidup $94.4 \%$.
\end{abstract}

Kata kunci : Aquaponik, Tingkat Kepadatan, Pendederan Nila

\section{PENDAHULUAN}

Ikan nila adalah salah satu jenis ikan air tawar yang populer di kalangan masyarakat. Oleh karena kepopulerannya membuat ikan nila cukup menjanjikan sebagai prospek usaha. Ditinjau dari aspek pertumbuhan, ikan nila termasuk ikan yang dapat tumbuh dengan cepat, memiliki bobot tubuh yang lebih besar, serta tingkat produktivitas yang tinggi.

Intensifikasi budidaya ikan ditandai dengan peningkatan padat tebar ikan serta pemberian pakan tambahan. Pada kondisi lingkungan yang optimum, serta pemberian pakan yang cukup, maka akan diperoleh peningkatan hasil yang bersumber dari peningkatan padat tebar ikan nila (Hepher dan Pruginin, 1981), (Yuliati, Kadarini, \& Subandiyah, 2003), dan (Diansari, Arini, \& Elfitasari, 2013). Hal ini berhubungan dengan daya dukung lingkungan (carrying capacity) yaitu kemampuan wilayah perairan dalam mendukung kehidupan ikan secara optimum selama periode waktu yang lama. Faktor-faktor yang mempengaruhi carrying capacity antara lain kualitas air, pakan, dan ukuran ikan. 


\section{Median Volume 11 Nomor 2 Bulan Juni}

Kekhasan rasa daging ikan nila yang berwarna putih bersih, tidak berduri, memiliki kandungan gizi yang cukup tinggi, sebagai sumber protein yang murah dan mudah didapat, serta harga jual terjangkau oleh masyarakat menjadi faktor lain yang berperan penting pada peningkatan prospek ikan nila di pasaran. Selain itu, pengembangan budidaya ikan nila juga diperkirakan memiliki prosepek yang sama baiknya dengan pengembangan jenis ikan konsumsi lainnya.

Ikan nila produktif apabila dipelihara di berbagai lahan, bukan hanya di kolam air tawar, tetapi juga dipelihara di tambak-tambak air payau dan laut. Hal ini karena ikan nila memiliki batasan toleransi yang cukup tinggi terhadap berbagai kondisi lingkungan perairan. Pada umumnya, ikan nila yang ukuran kecil lebih tahan terhadap perubahan lingkungan, dibanding dengan ikan nila ukuran yang lebih besar (Khairuman dan Amri, 2003).

Akuaponik (aquaphonic) adalah suatu inovasi teknologi budidaya yang mengkombinasikan pemeliharaan ikan dengan tanaman (Nelson, 1998). Akuaponik juga merupakan inovasi dari teknologi yang diterapkan pada budidaya ikan terintegrasi dengan tanaman melalui sistem akuaponik (Diver, 2006), dan (Nugroho, Pambudi, Chilmawati, \& Haditomo, 2012). Inovasi teknologi tersebut diperlukan untuk mencegah penurunan produksi akuakultur sebagai akibat penyusutan dari lahan budidaya serta kualitas perairan yang mengalami penurunan. Inovasi dari teknologi tersebut diharapkan mampu mengurangi produksi limbah serta meningkatkan produktivitas persatuan luas lahan pada kegiatan budidaya ikan. Teknologi akuaponik terbukti mampu berhasil memproduksi ikan secara optimal pada lahan sempit dan sumber air terbatas, termasuk di daerah perkotaan.

Teknologi ini pada prinsipnya, selain menghemat penggunaan lahan, air, serta dapat meningkatkan efisiensi usaha budidaya ikan, melalui pemanfaatan unsur hara yang bersumber dari sisa pakan, metabolisme ikan untuk tanaman air, serta sebagai suatu sistem akuakultur ramah lingkungan (Ahmad et al. 2007).

Sistem akuaponik dapat menghemat penggunaan air pada kegiatan budidaya ikan sampai 97\% dikarenakan ada interaksi antara ikan serta tanaman yang dapat menciptakan lingkungan yang lebih produktif dibanding metode konvensional (Saptarini, 2010) dalam Zidni et al (2013). Budidaya menggunakan sistem akuaponik lebih ramah lingkungan karena tidak menghasilkan limbah sehingga mengubah ammonia menjadi nitrit dan nitrat. Pada tanaman, nutrisi diperoleh dari nitrat yang bersumber dari air kaya nutrisi bersumber dari wadah pemeliharaan. Oleh karena itu penggunaan teknologi budidaya akuaponik diharapkan mampu memperbaiki kualitas air pada budidaya ikan dengan kepadatan tinggi sehingga dapat mengurangi tingkat kematian ikan.

Permasalahan yang sering dikeluhkan para pembudidaya ikan pada saat proses pemeliharaan adalah padat tebar benih ikan yang terbaik. Oleh karena itu, perlu diambil langkah-langkah dan menerapkan teknologi tepat guna agar dapat menambah nilai ekonomis pada usaha budidaya ikan yang dikombinasikan dengan aquaponik. Berdasarkan data tersebut di atas maka penulis mengambil judul penelitian tentang : Pengaruh padat tebar terhadap pertumbuhan Ikan Nila (Oreochromis niloticus) dalam sistem aquaponik Di Tambak PT. Radios Apirja Sorong. Penelitian ini bertujuan sebagai berikut : 1) Untuk mengetahui cara budidaya ikan nila dengan sistem aquaponik. 2) Untuk mengetahui tingkat kepadatan yang terbaik dalam pertumbuhan ikan nila dalam sistem akuaponik. 


\section{METODE PENELITIAN}

Penelitian ini akan dilaksanakan pada 14 Agustus sampai 17 September 2017 di Tambak PT. Radios Apirja Sorong. Penelitian ini bersifat eksperimen dan pengamatan (Kerlinger, 2006). Alat dan bahan pada penelitian ini adalah: termometer, $\mathrm{pH}$ meter, DO Meter, baskom, pompa celup, seser, timbangan digital, kamera digital, alat tulis, penggaris, pipa pvc, ikan nila, kangkung darat, pakan buatan (Tabel 1).

Metode dalam peneltian ini menggunakan metode eksperimen. Kerlinger, (2006) mengatakan bahwa eksperimen dalam suatu penelitian ilmiah dilakukan peneliti dengan memanipulasi, mengontrol satu atau lebih dari variabel bebas, melakukan pengamatan terhadap beberapa variabel terikat untuk menemukan variasi yang muncul secara bersamaan melalui manipulasi terhadap variabel bebas serta variabel yang akan dilihat pengaruhnya dinamakan variabel terikat.

\section{Prosedur PenelitiaN}

Prosedur penelitian yang dilakukan pada kegiatan penelitian ini adalah penyiapan wadah dan peralatan selama 1 - 2 Minggu sebelum melaksanakan kegiatan penelitian serta wadah penelitian dibersihkan agar terkondisikan steril dari penyakit. Persiapan biota percobaan ikan nila ukuran masing-masing antara 2-3 cm dan beserta pakan ikannya.

\section{Analisis Data}

Analisa data yang digunakan pada penelitian ini yaitu Rancangan Acak Lengkap (RAL). Rancangan Acak Lengkap merupakan rancangan yang paling sederhana, cocok untuk materi yang bersifat homogen yang artinya variasi diantaranya relatif kecil. Rancangan Acak Lengkap tidak memiliki lokal kontrol, sehingga cocok digunakan untuk kondisi lingkungan, alat, bahan dan media yang homogen seperti laboratorium, rumah kaca atau ruang-ruang terkontrol lainnya. (Hanafiah, 1991).

Rancangan Acak Lengkap (RAL) tersebut dilakukan dengan 4 (empat) perlakuan dengan masing-masing 3 (tiga) kali ulangan. Adapun perlakuan tersebut adalah :

1. Perlakuan A : Padat penebaran 20 ekor $/ 0,2 \mathrm{~m}^{2}$ dengan sistem aquaponik

2. Perlakuan B : Padat penebaran 25 ekor/ $0,2 \mathrm{~m}^{2}$ dengan sistem aquaponik

3. Perlakuan $\mathrm{C}$ : Padat penebaran 30 ekor/0,2 $\mathrm{m}^{2}$ dengan sistem aquaponik

4. Perlakuan D : Padat penebaran 35 ekor/0,2 $\mathrm{m}^{2}$ dengan sistem aquaponik

Tabel 1 : Komposisi Pakan

\begin{tabular}{|c|c|c|c|c|}
\hline Waktu & Dosis & Frekuensi & $\begin{array}{l}\text { Jenis } \\
\text { pakan }\end{array}$ & $\begin{array}{c}\text { Mutu/komposisi } \\
\text { pakan }\end{array}$ \\
\hline $\begin{array}{l}\text { 1. Pagi hari pukul } \\
08.00-08.30 \\
\text { 2. Sore hari pukul } \\
16.30-17.00\end{array}$ & $\begin{array}{l}5 \% \text { dari } \\
\text { bobot ikan }\end{array}$ & $2 \times$ sehari & $\begin{array}{l}\text { Pakan } \\
\text { buatan }\end{array}$ & $\begin{array}{ll}\text { 1. } & \text { Protein kasar } 35 \% \\
\text { 2. } & \text { Lemak kasar } 2 \% \\
\text { 3. } & \text { Serat kasar } 3 \% \\
\text { 4. } & \text { Abu kasar } 13 \% \\
\text { 5. } & \text { Kadar air } 12 \%\end{array}$ \\
\hline
\end{tabular}

Sumber : Daftar Label Pakan Merk FF 999 


\section{Median Volume 11 Nomor 2 Bulan Juni 2019}

Doi http://doi.org/md.v11i2.503

\section{HASIL DAN PEMBAHASAN}

\section{Pengukuran Pertumbuhan Berat}

Pengukuran pertumbuhan berat dilakukan sekali seminggu sehingga selama penelitian dilakukan penguk

uran berat dilakukan yaitu 5 (lima) kali pengukuran meliputi berat awal dan sampai pada minggu ke empat. Hasil pertumbuhan berat ikan nila dianalisis dengan dengan analisis sidik ragam anova.

Adapun hasil pengukuran berat selama penelitian adalah sebagai berikut :

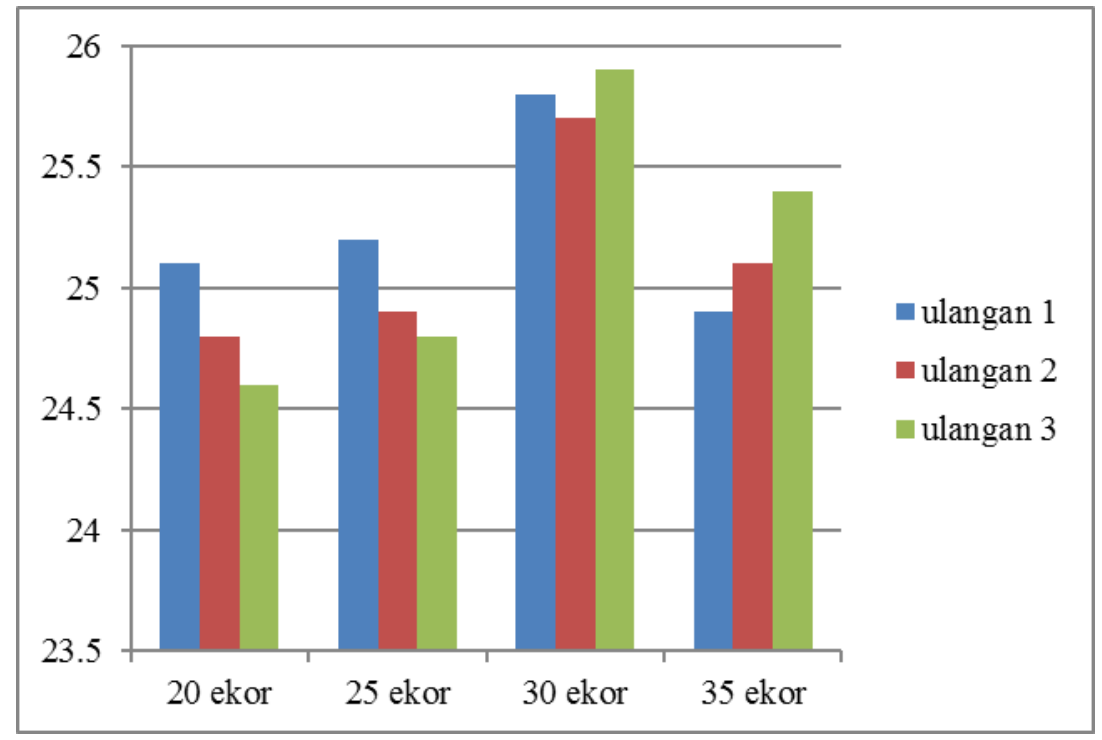

Gambar 1. Grafik pertumbuhan berat ikan

\section{Pengaruh padat penebaran terhadap pertumbuhan panjang}

Selain pengukuran pertumbuhan berat, pengukuran pertumbuhan panjang pun dilakukan pada penelitian ini dengan motode analisis statistik yang sama yaitu analisis sidik ragam anova. Adapun hasil pengukuran panjang yang didapatkan selama penelitian disajikan pada Gambar 2 di bawah ini.

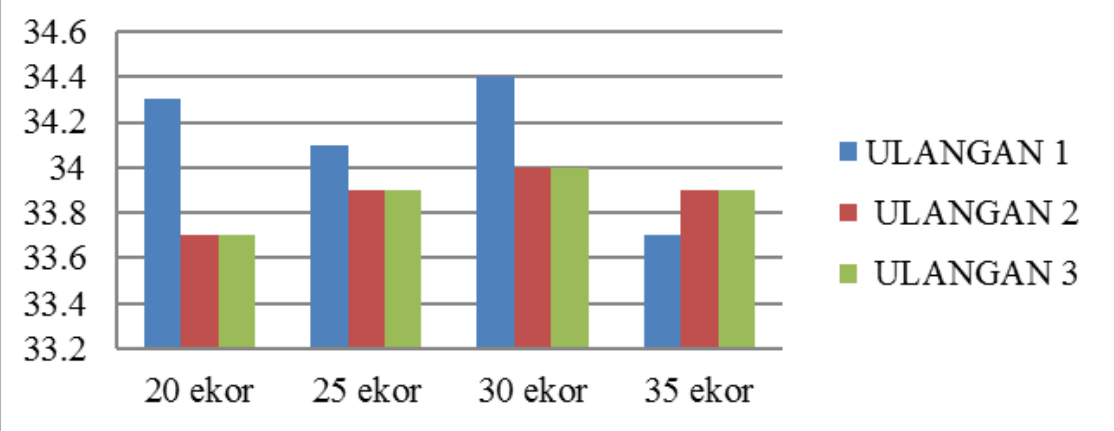

Gambar 2. Grafik pertumbuhan panjang ikan nila 


\section{Median Volume 11 Nomor 2 Bulan Juni}

Dari Gambar 2 di atas dapat dilihat bahwa pengaruh padat tebar terhadap pertumbuhan berat dan panjang ikan nila tidak memiliki pengaruh secara signifikan berdasarkan hasil uji sidik ragam anova menunjukkan bahwa secara statistik nilai keempat perlakuan tidak berbeda secara signifikan dimana nilai $\mathrm{f}$ tabel lebih besar daripada nilai $f$ hitung yang menandakan bahwa keempat perlakuan memiliki notasi yang sama. Sehingga tidak perlu melakukan uji statistik atau uji lanjutan seperti uji BNt karena nilai $\mathrm{f}$ hitung lebih rendah daripada $\mathrm{f}$ tabel. Sebagaimana pengalaman yang diungkapkan oleh Gomes dan Gomes (1984) dalam (Fahrizal \& Nasir, 2018) bahwa uji BNt akan dilakukan bila nilai $f$ tabel lebih rendah daripada $f$ hitung.

\section{Kelangsungan Hidup (Survival Rate atau SR)}

Tingkat kelangsungan hidup atau survival rate (SR) ikan adalah presentase jumlah ikan hidup pada saat waktu tertentu dibandingkan dengan jumlah ikan saat awal pemeliharaan. Untuk mengetahuinya digunakan rumus sederhana yang dikumkakan oleh Bachtiar, 2006 dalam (Fahrizal \& Nasir, 2018). yaitu jumlah ikan hidup dibagi dengan jumlah ikan tebar awal dikalikan dengan seratus persen. Selama penelitian, hasil yang diperoleh pada variable kelangsungan hidup ditampilkan pada Gambar 3 di bawah ini.

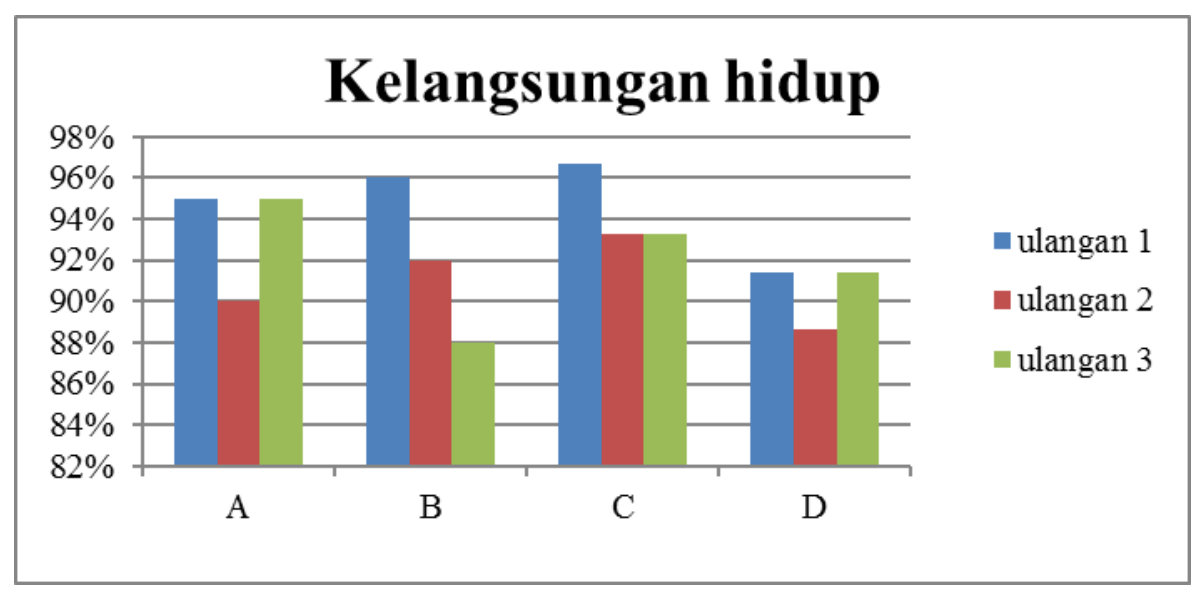

Gambar 3. Grafik Kelangsungan Hidup

Dari Gambar grafik 3 di atas dapat dilihat bahwa pengaruh padat tebar terhadap tingkat kelangsungan hidup pada ikan nila tidak memiliki pengaruh secara signifikan sebagaimana berdasarkan dari hasil uji sidik ragam Anova menunjukkan bahwa secara statistik nilai keempat perlakuan tidak berbeda secara siknifikan dimana nilai $\mathrm{f}$ tabel lebih besar daripada nilai f hitung yang menandakan bahwa keempat perlakuan memiliki notasi yang sama.

Dari Gambar 3 tersebut dapat dilihat bahwa perlakuan C memiliki rata-rata SR yang tinggi yaitu 94.4\%, kemudian perlakuan A memiliki SR kedua yaitu 93.3\%, perlakuan B memiliki SR ketiga yaitu 92\%, sedangkan perlakuan D memiliki SR rendah dibandingkan ketiga perlakuan lainnya yaitu $90.5 \%$. Hal ini berbeda dengan (Nugroho, Pambudi, Chilmawati, \& Haditomo, 2012) yang mengatakan bahwa Sintasan (kelangsungan hidup) rata-rata gelondongan pada budidaya ikan air tawar sebesar $84 \%$. Sementara (Fahrizal \& Nasir, 2018) mengatakan bahwa SR ikan nila yang diberikan probiotik dengan dosis berbeda mencapai $100 \%$.

Untuk mempertahankan SR serta pertumbuhan ikan, maka diperlukan makanan yang memenuhi nutrisi ikan. Faktor yang mempengaruhi kelangsungan hidup ikan 
adalah padat tebar, pemberian pakan, penyakit dan kualitas air yang meliputi suhu, kadar amoniak dan nitrit, oksigen terlarut, $\mathrm{pH}$ perairan. Nilai tingkat kelangsungan hidup ikan yang baik rata-rata 63,5 - 86,0 (DEPTAN, 1999) dalam (Fahrizal \& Nasir, 2018).

\section{Nilai FCR (Feed Conversion Ratio)}

Konversi pakan atau Feed Conversion Ratio (FCR) dan efisiensi pakan secara umum diartikan sebagai indikator untuk menentukan efektifitas pakan. Konversi pakan adalah kemampuan kultivan akuakultur mengubah pakan menjadi daging sedangkan efisiensi pemberian pakan yaitu bobot basah daging ikan yang diperoleh per satuan berat kering pakan yang diberikan (Watanabe, 1988, dalam Idil Ardi, 2013).

Soetomo (1990) dalam (Fahrizal \& Nasir, 2018) mengatakan bahwa nilai konversi pakan menunjukan sejauh mana makanan efesien dimanfaatkan oleh ikan budidaya. Selain itu, oksigen secara tidak langsung turut mempengaruhi besar kecilnya konversi pakan. Nilai FCR yang dihasilkan selama penelitian dari tiga perlakuan 1 dapat dilihat pada Gambar grafik 4 di bawah ini.

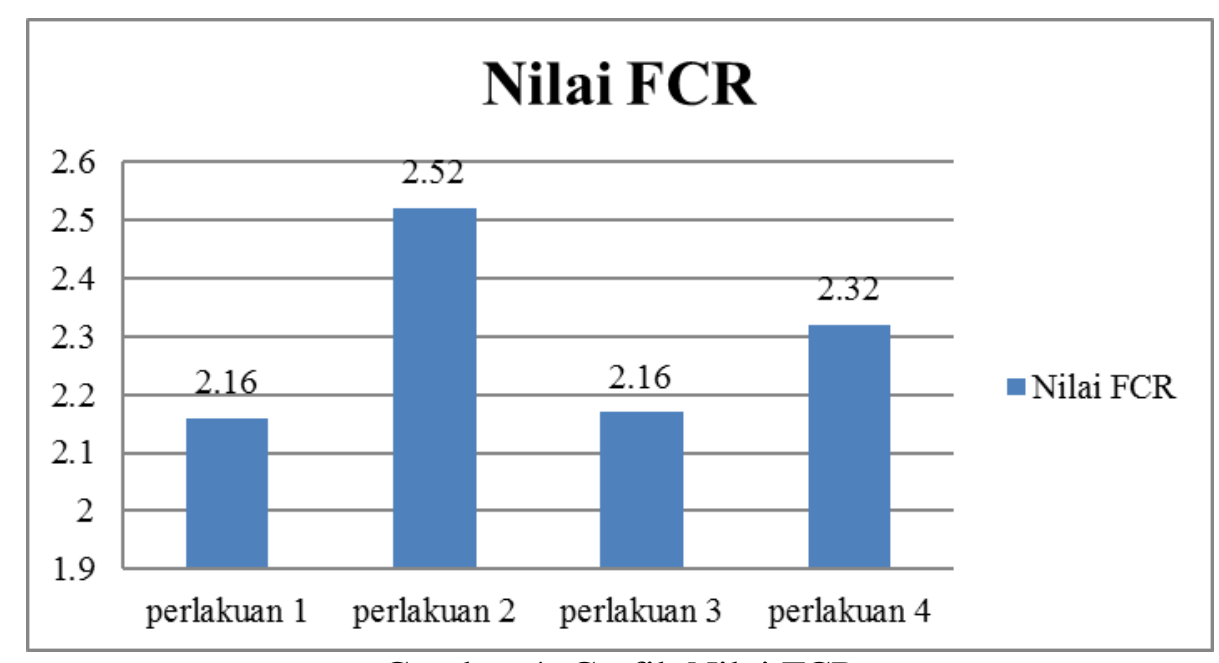

Gambar 4. Grafik Nilai FCR

Berdasarkan Gambar grafik 4 di atas bahwa padat penebaran benih ikan nila sebanyak 20 ekor menghasilkan nilai FCR sebesar 2.16, pada padat tebar benih 25 ekor menghasilkan nilai FCR sebesar 2.52, padat penebaran benih ikan nila 30 ekor, nilai FCR sebesar 2.16, dan pada padat penebaran benih 35 ekor dihasilkan nilai FCR yaitu 2.32. Dengan hasil ini dapat diketahui bahwa nilai FCR yang terbaik terjadi pada perlakuan pertama dan ketiga dengan padat penebaran benih ikan nila 20 ekor dan 30 ekor. Hal ini berbeda dengan yang dikemukakan oleh (Putra, Setiyanto, \& Wahyjuningrum, 2011) dan (Fahrizal \& Nasir, 2018) bahwa nilai FCR ikan nila sebesar 1.7 - 1,73. (Effendy, 2004), mengemukakan bahwa semakin besar nilai FCR, maka semakin banyak pakan yang dibutuhkan untuk menghasilkan $1 \mathrm{~kg}$ ikan. Dimana nilai FCR ikan berkisar antara 1,5-2,5.

\section{Efisiensi Pemberian Pakan}

Efisiensi pakan dimaknai bobot basah daging ikan yang diperoleh per satuan berat kering pakan yang diberikan atau merupakan presentase dari berat ikan yang dihasilkan 


\section{Median Volume 11 Nomor 2 Bulan Juni}

dibandingkan dengan berat pakan yang diberikan. Hal ini sangat berguna untuk membandingkan nilai pakan yang mendukung pertambahan bobot. Efisiensi pakan berubah seiring dengan laju pemberian pakan serta ukuran ikan. Efisiensi pakan dipengaruhi oleh beberapa faktor diantaranya kualitas pakan, jumlah pakan, spesies ikan, ukuran ikan dan kualitas air. Adapun nilai efisiensi pemberian pakan yang didapatkan pada penelitian ini ditampilkan pada Gambar 5 di bawah ini.

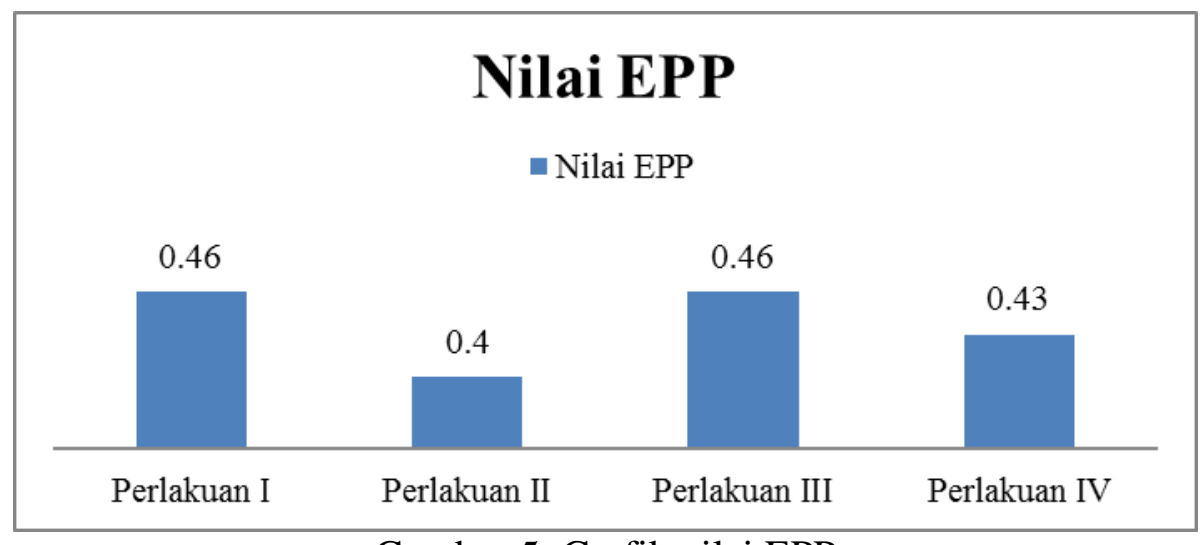

Gambar 5. Grafik nilai EPP

Dilihat dari Gambar grafik 5 di atas bahwa pada padat tebar 20 ekor diperoleh nilai EPP sebesar 46\%, padat penebaran 25 ekor dihasilkan nilai EPP yaitu 40\%, padat penebaran 30 ekor dihasilkan nilai EPP yaitu 46\%, padat penebaran 35 ekor dihasilkan nilai EPP sebesar 43\%. Dengan hasil ini dapat diketahui bahwa nilai EPP yang terbaik terjadi pada perlakuan pertama dan ketiga dengan pemberian dosis pakan pada perlakuan pertama dan ketiga diperoleh nilai EPP 46\%. Hal ini menunjukkan bahwa dengan pemberian pakan $1 \mathrm{~kg}$ maka akan berubah menjadi daging ikan sebanyak 0.46 $\mathrm{kg}$.

Hal ini berbeda dengan yang disampaikan oleh (Noviana, 2014) bahwa pada benih ikan nila yang diberikan pakan buatan dengan penambahan probiotik sebesar $10 \mathrm{~g} / \mathrm{kg}$ diperoleh efisiensi pemanfaatan pakan sebesar 77.23\%. Penggunaan probiotik dengan dosis $15 \mathrm{ml}$ diperoleh nilai EPP sebesar 58\% (Fahrizal \& Nasir, 2018). Hal ini menunjukkan bahwa setiap pemberian pakan sebanyak $1 \mathrm{~kg}$ dan yang berubah menjadi daging sebesar $0.58 \mathrm{~kg}$. Hal ini menunjukkan nilai efisien pakan yang baik menurut pernyataan Dirjen Perikanan (1985) dalam P. A. Koroh, Lumenta (2014) bahwa pakan yang baik disyaratkan agar mempunyai nilai efisiensi pakan lebih dari $25 \%$.

\section{Panen}

Dalam usaha budidaya ikan kegiatan panen merupakan faktor yang paling mempengaruhi keberhasilan. Pemanenan memerlukan pengaturan yang tepat agar mendapatkan hasil yang maksimal. Ada dua jenis tipe pemanenan yaitu pemanenan sebagian dan keseluruhan. Pada pemanenan sebagian umumnya yang dipanen adalah tanaman. Pemanenan tanaman umumnya dapat dilakukan beberapa kali dalam satu masa pemeliharaan budidaya ikan.

Pada pemanenan keseluruhan atau total, dua jenis komoditas dipanen pada hari yang sama. Secara umum dalam hal pemanenan secara total, panen tanaman dilakukan 


\section{Median Volume 11 Nomor 2 Bulan Juni}

Doi http://doi.org/md.v11i2.503

dan diselesaikan terlebih dahulu dibandingkan panen ikan.diharapkan dengan cara panen ini maka tanaman sayuran yang dipanen masih dalam keadaan segar.

\section{KESIMPULAN}

Dari hasil penelitian yang dilakukan dapat disimpulkan bahwa :

1. Budidaya ikan nila menggunakan teknologi aquaponik pada dasarnya terbagi atas teknologi pemeliharaan ikan sebagai basis pokok budidaya dan pemeliharaan tanaman. Tahapan - tahapan budidaya ikan nila aquaponik pada umumnya hampir sama dengan budidaya ikan seperti, persiapan budidaya, pemeliharaan ikan tanaman dan panen dan pasca panen.

2. Padat penebaran ikan nila pada sistem aquaponik yang ideal adalah pada perlakuan ketiga yaitu dengan tingkat kepadatan 30 ekor dan tingkat SR yaitu 94.4\%.

\section{AKNOWLEDGMENT}

Terima kasih yang sebesar-besarnya Penulis ucapkan terhadap PT. Radios Apirja atas ijin penggunaan lahan yang telah diberikan selama melakukan penelitian sehingga penelitian ini dapat berjalan dengan baik

\section{DAFTAR PUSTAKA}

Ahmad, T., L. Sofiarsih, dan Rusmana. 2007. The growth of Patin Pangasius hypopthalmus in a close system tank. Journal Aquaculture, 2 (1): 67-73.

Diver, S. 2006. Aquaponics - Integration of Hydroponics with Aaquaculture. National Sustainable. Agriculture Information Service, Australia.

Diansari, R., Arini, E., \& Elfitasari, T. (2013). Pengaruh kepadatan yang berbeda terhadap kelulushidupan dan pertumbuhan ikan nila (Oreochromis niloticus) pada sistem resirkulasi dengan filter zeolit. Journal of Aquaculture Management and Technology, 37-45.

Effendy, I. 2004 pengantar akuakultur. Jakarta: penebar swadaya.

Fahrizal, A., \& Nasir, M. (2018). Pengaruh Penambahan Probiotik Dengan Dosis Berbeda Pada Pakan Terhadap Pertumbuhan Dan Rasio Konversi Pakan (Frr) Ikan Nila (Oreochromis Niloticus). MEDIAN, 69-80.

Hanafiah K.A., 1991. Rancangan Percobaan Teori dan Aplikasi. PT. Raja Grafindo Persada, Jakarta.

I. Ardi, 2013. Budidaya Ikan Sistem Keramba Jaring Apung Guna Menjaga Keberlanjutan Lingkungan Perairan Waduk Cirata. Pusat Penelitian dan Pengembangan Perikanan Budidaya Jl. Ragunan 20, Pasar Minggu, Jakarta Selatan 12540 E-mail: $\quad$ HYPERLINK "mailto:ardiidil@yahoo.com" ardiidil@yahoo.com . Media Akuakultur Volume 8 Nomor 1 Tahun 2013. Halaman $23-29$.

Kerlinger. 2006. Asas-asas Penelitian Behavioral Edisi Ketiga. Yogjakarta: Gajah Mada University Press.

HYPERLINK

"http://www.eurekapendidikan.com/2015/11/metode-penelitian-

eksperimen.html?m=1" www.eurekapendidikan.com/2015/11/metode-penelitianeksperimen.html?m=1 . Diakses pada tanggal 20 Mei 2016.

Khairuman dan Amri K. 2003. Budidaya Ikan Nila Secara Intensif. Agromedia Pustaka, Jakarta. 


\section{Median Volume 11 Nomor 2 Bulan Juni}

Nelson, R.1998. Aquaponics Journal Voi.N No.5. Nelson/Pade Multimedia PO Box 1848Program Studi Teknologi dan Manajemen Akuakultur. Fakultas Perikanan dan Kelautan, Institut Pertanian Bogor.

Noviana, P. (2014). Pengaruh Pemberian Probiotik Dalam Pakan Buatan Terhadap Tingkat Konsumsi Pakan Dan Pertumbuhan Benih Ikan Nila (Oreochromis Niloticus). Journal of Aquaculture Management and Technology, 183-190.

Nugroho, R., Pambudi, L., Chilmawati, D., \& Haditomo, A. (2012). Aplikasi Teknologi Aquaponic pada budidaya ikan air tawar untuk optimalisasi kapasitas produksi. AINTEK PERIKANAN: Indonesian Journal of Fisheries Science and Technology, 46-51.

Putra, I., Setiyanto, D., \& Wahyjuningrum, D. (2011). Pertumbuhan dan kelangsungan hidup ikan nila Oreochromis niloticus dalam sistem resirkulasi. Jurnal Perikanan dan Kelautan, 56-63.

P. A. Koroh, dan C. Lumenta. 2014. Pakan suspensi daging kekerangan bagi pertumbuhan benih sidat (Anguilla bicolor). (Mussel flesh suspension food for growth of elver, Anguilla bicolor). Jurnal Budidaya Perairan. Vol. 2 No. 1: 7 13.

Soetomo, M.1990. Teknik Budidaya Udang Windu. Sinar Baru. Bandung.115 Hlm

Yuliati, P., Kadarini, T., \& Subandiyah, S. (2003). PADAT PENEBARAN TERHADAP PERTUMBUHAN DAN SINTASAN DEDERAN IKAN NILA GIFT (Oreochromis niloticus) DI KOLAM [Effect of Stocking Density on Growth and Survival Rates of Oreochromis niloticus in the Pond]. Jurnal Iktiologi Indonesia, 63-66.

Zidni, Irfan., T. Herawati, dan E. Liviawaty. 2013. "Pengaruh Padat Tebar Terhadap Pertumbuhan Benih Lele Sangkuriang (Clarias gariepinus) dalam Sistem Akuaponik". Jurnal Perikanan Kelautan. Vol.4 No.4, Desember 2013. 